\title{
ВЫЯВЛЕНИЕ И ПРЕСЕЧЕНИЕ АДМИНИСТРАТИВНЫХ ПРАВОНАРУШЕНИЙ, КАК ОДИН ИЗ СПОСОБОВ ПРОФИЛАКТИКИ ПРЕСТУПЛЕНИЙ
}

\author{
Лаврентьева М.С., Туркин М.М.
}

Аннотация: По данным официальной статистики в 2014 году было возбуждено 1728643 уголовных дела по различным преступлениям, при этом органами внутренних дел (полицией) было пресечено 76577620 административных правонарушений. Такие данные свидетельствуют о разнице в количестве выявленных преступлений и административных правонарушений. Юристы признают, что одним из основных направлений борьбы с преступностью должна являться сфера превентивного воздействия, включающая в себя не только выявление, но и нейтрализацию причин и условий такого негативного явления. Для достижения цели и решения задач, стоящих перед исследованием были применены общенаучные и частно-научные методы: анализ, синтез, структурно-логический метод, статистический и иные методы научного познания. Отсутствие в законодательстве об административных правонарушениях института покушения обусловливает неопределенность установления момента окончания мелкого хищения, приводит к неоднозначному толкованию нормы в судебной практике и в актах толкования Верховного Суда РФ. В иелях устранения данной проблемы и приведения ст. 7.27 КоАП РФ в соответствие сложившейся правоприменительной практике предлагаем установить административную ответственность не только за оконченное мелкое хищение, но и за покушение на мелкое хищение, что будет являться предупреждением более вредных и общественно-опасных деяний-преступлений.

Ключевые слова: Выявление, пресечение, административное правонарушение, способ, профилактика, преступление, административное наказание, мелкое хищение, защита, распоряжение похищенным.

По данным официальной статистики в 2014 году было возбуждено 1728643 уголовных дела по различным преступлениям, при этом органами внутренних дел (полицией) было пресечено 76577620 административных правонарушений.[1] Такие данные свидетельствуют о разнице в количестве выявленных преступлений и административных право- нарушений. Юристы признают, что одним из основных направлений борьбы с преступностью должна являться сфера превентивного воздействия, включающая в себя не только выявление, но и нейтрализацию причин и условий такого негативного явления. Многие ученые, признавая ограниченные возможности карательного воздействия государства на 
лиц, совершающих преступления, пытались сформулировать принципы функционирования системы профилактики, позволившей бы максимально, по возможности, снизить уровень преступности и прогнозировать основные тенденции, способствующие ее развитию.

На наш взгляд, необходимым условием успешной профилактики преступности является наличие соответствующей нормативно-правовой базы, возможно включающей в себя ряд источников, регламентирующих деятельность различных субъектов профилактики правонарушений на основе принципов и положений, призванных эффективно защищать законные права и интересы человека и гражданина.

Нельзя не согласиться с научной точкой зрения, которая к одному из видов профилактики преступлений относит привлечение правонарушителя к более «мягкой» - административной ответственности. И административное наказание, например, за совершение кражи назначается по ст.7.27 КоАП РФ. При этом решение вопроса о сущности или содержании административного наказания начинается с выяснения его цели. Правильное определение целей административного наказания в законе предполагает теоретическое изыскание не только вопроса о том, какие цели должны ставиться перед таким наказанием, но и какие цели ставиться не должны в силу того, что не могут быть достигнуты с помощью административного наказания. Верное решение таких проблем послужит «увеличению» эффективности административно - деликтного закона и практического его применения.

Ст. 3.1 КоАП РФ выделяет в качестве цели административного наказания предупреждение совершения новых правонарушений, как самим нарушителем, так и другими лицами, т.е. цель административного наказания выступает одновременно и обоснованием установки тех результатов, достижение которых желательно путем применения административного наказания. Таким образом, цели административного наказания следует рассматривать как конечный результат, которого стремится достичь государ- ство, порицая виновного за совершение административного правонарушения.

Говоря о целях административной ответственности и административного наказания в частности, хотелось бы обратить внимание на такое распространенное правонарушение как - мелкое хищение чужого имущества, так за 2014 год в России было выявлено 128026 административных правонарушений, предусмотренных ст. 7.27 КоАП РФ, и, в то же время, 294478 преступлений, предусмотренных ч.1 ст. 158 УК РФ, не считая других видов уголовно наказуемого хищения, что, конечно же, не отражает реальное положение дел. В действительности правонарушений совершается в несколько раз больше, чем уголовно-наказуемых, что зачастую обусловлено отсутствием желания у потерпевшего обращаться в правоохранительные органы из-за незначительного ущерба.

Кража всегда совершается тайно. В соответствии с Постановлением Пленума Верховного Суда РФ «О судебной практике по делам о краже, грабеже и разбое от 27 декабря 2002 года № 29, «тайное хищение чужого имущества (кражу) следует квалифицировать как действия лица, совершившего незаконное изъятие имущества в отсутствие собственника или иного владельца этого имущества, или посторонних лиц либо хотя и в их присутствии, но незаметно для них. В тех случаях, когда указанные лица видели, что совершается хищение, однако виновный, исходя из окружающей обстановки, полагал, что действует тайно, содеянное также является тайным хищением чужого имущества, а также «если лицо ошибочно полагало, что совершает хищение тайно, а в действительности его действия осознавал потерпевший или наблюдали другие лица, то в соответствии с направленностью умысла содеянное должно квалифицироваться как кража». Важное значение имеет точное установление момента окончания кражи чужого имущества, хотя следует заметить, что в правовой литературе единообразное решение вопроса отсутствует. Одни ученые считают кражу окон- 
ченной с момента изъятия имущества, независимо от того, успел ли преступник завладеть этим имуществом и распорядиться им по своему усмотрению [2]. Наряду с этой позицией существует и несколько иная точка зрения, согласно которой кража считается оконченной с момента, когда уничтожается, прекращается правомерное владение имуществом, и оно переходит посредством изъятия в фактическое владение виновного. При таком понимании для момента окончания кражи не требуется наступления условий, дающих возможность распорядиться (воспользоваться) имуществом, достаточно самого факта преступного обладания этим имуществом [3].

Наконец, существует и третья точка зрения, основанная на так называемой теории распоряжения, согласно которой кражу следует считать оконченной, когда виновный получил реальную возможность распорядиться похищенным по своему усмотрению [4]. Сторонники этой точки зрения исходят из того, что необходимым последствием кражи является не только лишение собственника или владельца имущества, но и реальная возможность распоряжаться похищенным, что на момент изъятия похищенного, как известно, отсутствует. По их мнению, перенесение момента окончания кражи на более раннюю стадию преступной деятельности не оправдано, ибо в этом случае покушение фактически признается оконченным деянием, что должно привести к необоснованному усилению ответственности и наказания [5].

Обычно для определения момента окончания хищения, необходимо было обращаться к постановлениям Пленумов Верховного Суда СССР, РСФСР, РФ. Так, в п. 10 Постановления Пленума Верховного Суда СССР «О судебной практике по делам о хищениях государственного и общественного имущества от 11 июля 1972 г. № 4 указывалось: «Хищение следует считать оконченным, если имущество изъято и виновный имеет реальную возможность им распоряжаться по своему усмотрению и пользоваться им». Пункт 14 Постановления Пленума Верховного Суда СССР «О судебной практике по делам о преступлениях против личной собственности» от 5 сентября 1986 г. № 11 продолжает ранее начатое утверждение о том, что кража, грабеж и мошенничество считаются оконченными, если имущество изъято и виновный имеет реальную возможность пользоваться или распоряжаться им по своему усмотрению [6]. Постановление Пленума Верховного Суда СССР «О судебной практике по делам о краже, грабеже и разбое» от 27 декабря 2002 г. № 29 подтвердило признанную позицию [7]. Таким образом, все постановления Пленумов Верховного Суда придерживались теории распоряжения, за исключением Постановления Пленума Верховного Суда РСФСР от 22 марта 1966 г.

Между тем, необходимо отметить, что до настоящего времени законодательством не разъяснено, что понимать под реальной возможностью распоряжаться похищенным имуществом. В связи с этим в судебно-следственной практике возникают серьезные трудности по установлению момента окончании кражи.

В соответствии с п. 19 Постановления Пленума Верховного Суда РФ от 24 марта 2005 года: Кодексом Российской Федерации об административных правонарушениях предусмотрена возможность привлечения к административной ответственности только за оконченное правонарушение [8]. Т.е. лицо не может быть привлечено к административной ответственности за правонарушение, формально характеризуемое как оконченное, в случае, если фактически деяние не содержит юридических признаков, позволяющих утверждать, что оно окончено. По своим формальным признакам мелкое хищение - правонарушение оконченное. Оно не может быть длящимся, но может быть продолжаемым. Равно как и хищение, предусмотренное уголовным законом, однако уголовное законодательство, в отличие от административного, устанавливает ответственность не только за оконченное преступление, но и за покушение на преступление. Следовательно, для реализации административной ответственности необходимо точно определить момент окончания правонарушения. 
Учитывая, что диспозиция ст. 7.27 КоАП РФ для квалификации деликта отсылает нас к уголовному кодексу, необходимо провести сравнительный анализ признаков оконченности мелкого хищения в соответствии с КоАП РФ и хищения в соответствии с УК РФ, а также толкования соответствующих норм Верховным Судом РФ.

В практике уголовного судопроизводства данный вопрос решается в соответствии с гл. 6 УК РФ. такие преступления как кража, мошенничество, присвоение или растрата являются материальными и считаются оконченными, с момента получения виновным возможности распорядится похищенным по своему усмотрению независимо от того, удалось ли ему эту возможность реализовать[9]. Покушением на совершение преступления, в соответствии с ч. 3 ст. 30 УК РФ, признаются умышленные действия (бездействия) лица, непосредственно направленные на совершение преступления, если при этом преступление не было доведено до конца по не зависящим от этого лица обстоятельствам.

Однако в административном законодательстве отсутствует институт покушения. Как уже указывалось ранее, административная ответственность наступает лишь за оконченные правонарушения. Таким образом, ответственности за покушение на мелкое хищение имущества нет, и, учитывая, что по правилам уголовного судопроизводства лицо не может распорядиться похищенным, а правонарушение не доведено до конца, привлечь виновного к ответственности не представляется возможным.

По мнению Верховного Суда РФ, под хищением понимаются совершенные с корыстной целью противоправное безвозмездное изъятие и (или) обращение чужого имущества в пользу виновного или других лиц, причинившие ущерб собственнику или иному владельцу этого имущества. Мелкое хищение путем кражи образует состав административного правонарушения с момента тайного изъятия чужого имущества и возможности им распорядиться. С субъективной стороны хищение предполагает наличие у виновного лица прямого умысла, направленно- го на завладение чужим имуществом с целью обращения его в свою пользу. Следовательно, с момента изъятия имущества у собственника, виновное лицо имеет реальную возможность распорядиться таким имуществом. Таким образом, в действиях лица неправомерно завладевшим имуществом стоимостью менее 1000 рублей, присутствует умысел на завладение чужим имуществом, т.е. происходит его фактическое изъятие и содеянное образует состав правонарушения, предусмотренный ст. 7.27 КоАП РФ, несмотря на то, что данное лицо было задержано на проходной предприятия или на кассе магазина, а не за его пределами [10].

Заметим, что Пленум Верховного Суда РФ в постановлении от 24 марта 2005 г. однозначно отрицает возможность привлечения к административной ответственности за неоконченное правонарушение. Однако в действительности ответственность за неоконченные правонарушения в некоторых случаях прямо предусмотрена КоАП РФ. Так, например правонарушение, предусмотренное ст. 19.12 КоАП РФ: «Передача либо попытка передачи запрещенных предметов лицам, содержащимся в учреждениях уголовно-исполнительной системы, следственных изоляторах или изоляторах временного содержания». Исходя из диспозиции данной статьи, становится понятно, что наказуемы не только передача, но и попытка передачи запрещенных предметов, веществ или продуктов питания, приобретение, хранение или использование которых запрещено. Учитывая, что административная ответственность наступает в данном случае, как за передачу, так и за попытку передачи запрещенных предметов, веществ или продуктов питания, приобретение, хранение или использование которых запрещено, административное правонарушение в этом случае является неоконченным и ответственность наступает за покушение. Точнее, уже сама попытка передачи указанных предметов квалифицируется как оконченное правонарушение, равно как и состоявшаяся передача [11].

В свое время известный советский и российский административист профессор Д.Н. Бахрах 
предлагал внести изменения в действующий тогда Кодекс РСФСР об административных правонарушениях и установить административную ответственность за покушение на совершение административного правонарушения [12].

Отсутствие в законодательстве об административных правонарушениях института покушения обусловливает неопределенность установления момента окончания мелкого хищения, приводит к неоднозначному толкованию нормы в судебной практике и в актах толкования Верховного Суда РФ. В целях устранения данной проблемы и приведения ст. 7.27 КоАП РФ в соответствие сложившейся правоприменительной практике предлагаем установить административную ответственность не только за оконченное мелкое хищение, но и за покушение на мелкое хищение, что будет являться предупреждением более вредных и общественно-опасных деяний - преступлений.

\section{Библиография:}

1. https://mvd.ru/Deljatelnost/statistics/reports/

2. Якубович М.И. Советское уголовное право. Общая и Особенная части. М., 1962. С. 312; Сирота С.И. Преступления против социалистической собственности и борьба с ними. Воронеж, 1968. С. 66.

3. Гельфер В.А., Литовченко С.П. Момент окончания преступления при краже Социалистическая законность. М. 1972. № 11. С. 43; Владимиров В.А. Социалистическая собственность под охраной закона. М., 1979. С. 29.

4. Кузнецов А.В. Спорные вопросы квалификации хищений // Сб. научных трудов ВНИИ МВД СССР. Вып. 22. М., 1972. С. 26; Кригер Г.А. Квалификация хищений чужого имущества. М., 1974. С. 109; Загородников Н.Н. Советское уголовное право. Общая и Особенная части. М., 1976. С. 307 ; Милюков С. Критерии определения момента окончания хищения чужого имущества // Советская юстиция. 1984. № 7. С. 11-12.

5. Буз С.И. Кража: уголовно-правовые и криминологические аспекты: Дис... канд. юрид. наук. Ростов-на-Дону, 2002. С. 75.

6. Сборник постановлений Пленумов Верховных Судов СССР и РСФСР по уголовным делам. М., 1996. С. 313.

7. Российская газета. 2003. 5 января.

8. Постановления Пленума Верховного Суда РФ от 24 марта 2005 года №5 (ред. От 11.11.2008) «О некоторых вопросах, возникающих у судов при применении Кодекса Российской Федерации об административных правонарушениях.

9. Комментарий к ст. 158 // Комментарий к Уголовному кодексу Российской Федерации (постатейный) под ред. А.И. Чучаева «КОНТРАКТ», «ИНФРА-М», М., 2009.

10. Обзор законодательства и судебной практики Верховного Суда Российской Федерации за первый квартал 2006 г. (утв. постановлением Президиума Верховного Суда РФ от 7 и 14 июня 2006 г.)

11. Лаврентьева М.С., Туркин М.М. К вопросу о мелких хищениях на объектах транспорта. М., 2010. С. 65.

12. Бахрах Д.Н. Состав административного проступка: Уч. пособие. Свердловск, 1987. С. 33.

\section{References (transliterated):}

1. https://mvd.ru/Deljatelnost/statistics/reports/

2. Yakubovich M.I. Sovetskoe ugolovnoe pravo. Obshchaya i Osobennaya chasti. M., 1962. S. 312; Sirota S.I. Prestupleniya protiv sotsialisticheskoi sobstvennosti i bor'ba s nimi. Voronezh, 1968. S. 66. 
3. Gel'fer B.A., Litovchenko S.P. Moment okonchaniya prestupleniya pri krazhe Sotsialisticheskaya zakonnost'. M. 1972. № 11. S. 43; Vladimirov V.A. Sotsialisticheskaya sobstvennost' pod okhranoi zakona. M., 1979. S. 29.

4. Kuznetsov A.V. Spornye voprosy kvalifikatsii khishchenii // Sb. nauchnykh trudov VNII MVD SSSR. Vyp. 22. M., 1972. S. 26; Kriger G.A. Kvalifikatsiya khishchenii chuzhogo imushchestva. M., 1974. S. 109; Zagorodnikov N.N. Sovetskoe ugolovnoe pravo. Obshchaya i Osobennaya chasti. M., 1976. S. 307; Milyukov S. Kriterii opredeleniya momenta okonchaniya khishcheniya chuzhogo imushchestva // Sovetskaya yustitsiya. 1984. № 7. C. 11-12.

5. Buz S.I. Krazha: ugolovno-pravovye i kriminologicheskie aspekty: Dis... kand. yurid. nauk. Rostovna-Donu, 2002. S. 75.

6. Sbornik postanovlenii Plenumov Verkhovnykh Sudov SSSR i RSFSR po ugolovnym delam. M., 1996. S. 313.

7. Rossiiskaya gazeta. 2003. 5 yanvarya.

8. Postanovleniya Plenuma Verkhovnogo Suda RF ot 24 marta 2005 goda №5 (red. Ot 11.11.2008) «O nekotorykh voprosakh, voznikayushchikh u sudov pri primenenii Kodeksa Rossiiskoi Federatsii ob administrativnykh pravonarusheniyakh.

9. Kommentarii k st. 158 // Kommentarii k Ugolovnomu kodeksu Rossiiskoi Federatsii (postateinyi) pod red. A.I. Chuchaeva «KONTRAKT», «INFRA-M», M., 2009.

10. Obzor zakonodatel'stva i sudebnoi praktiki Verkhovnogo Suda Rossiiskoi Federatsii za pervyi kvartal 2006 g. (utv. postanovleniem Prezidiuma Verkhovnogo Suda RF ot 7 i 14 iyunya 2006 g.)

11. Lavrent'eva M.S., Turkin M.M. K voprosu o melkikh khishcheniyakh na ob"ektakh transporta. M., 2010. S. 65.

12. Bakhrakh D.N. Sostav administrativnogo prostupka: Uch. posobie. Sverdlovsk, 1987. S. 33. 